\title{
Low-Temperature Interaction of Dioxygen and Carbon Monoxide with Microporous Films of Co(II) Porphyrins Containing Bulky tert-Butyl Substituents
}

\author{
Tigran S. Kurtikyan, ${ }^{\mathrm{a}}$ Astghik A. Hovhannisyan, ${ }^{\mathrm{a}}$ Alexey V. Lyubimtsev, ${ }^{\mathrm{b}}$

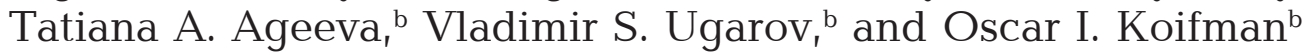 \\ ${ }^{a}$ Molecule Structure Research Center of Scientific and Technological Center of Organic and Pharmaceutical Chemistry NAS, \\ 0014 Yerevan, Armenia \\ ${ }^{\mathrm{b}}$ Research Institute of Macroheterocycles, Ivanovo State University of Chemical Technology, 153000 Ivanovo, Russia \\ ${ }^{\circledR}$ Corresponding authorE-mail: kurto@netsys.am
}

\begin{abstract}
The low-temperature interaction of $\mathrm{O}_{2}, \mathrm{CO}$ and their mixtures with sublimed layers of Co(II) complexes of 5,10,15,20-tetrakis(3',5'-di-tert-butylphenyl)porphyrin (I) and 5-(pyridin-4'-yl)-10,15,20-tris(3',5'-di-tert-butylphenyl)porphyrin (II) has been studied by FTIR and optical spectroscopy. In contrast to the layers of [5,10,15,20-tetraphenylporphyrinato]cobalt(II) Co(TPP), that lose their porosity and ligand-binding ability upon standing at ambient conditions overnight, the films of I conserve these properties for a long time. Thus the bulky tert-butyl groups of $\boldsymbol{I}$ substantially slow down the close packing of molecules in the films making metal ions accessible to different ligands. It is shown that the films of II consist of coordination oligomers, the sixth coordination site of which is occupied by the pyridyl group of an adjacent molecule in the film. The reaction of $\mathrm{O}_{2}$ gas with these films leads to the formation of two types of complexes: six-coordinate dioxygen complexes, in which the fifth site is occupied by the pyridyl group of the neighboring molecule in the film and the five-coordinate dioxygen complexes that terminate the oligomers. Upon storage of the films, the concentration of six-coordinate complexes increases at the expense of the five-coordinate indicating increasing degree of oligomerization. In contrast, only the end group of oligomers is able to coordinate carbon monoxide CO. No six-coordinate complexes of $C O$ with trans pyridyl group are formed in the films of II and the 6-coordination sites of oligomers remain free. When $\mathrm{CO} / \mathrm{O}_{2}$ mixture is admitted into the cryostat with films of II these sites selectively bind $\mathrm{O}_{2}$. This phenomenon allows eliminating $\mathrm{O}_{2}$ from the $\mathrm{CO} / \mathrm{O}_{2}$ mixture containing very low concentrations of $\mathrm{O}_{2}$ and can be used for $C O$ purification of trace quantities of dioxygen.
\end{abstract}

Keywords: Microporous metalloporphyrin films, Co porphyrins, bulky meso-substituents, coordination oligomers, $\mathrm{O}_{2}$ and $\mathrm{CO}$ adducts, FTIR and optical spectra, gas separation, low temperatures.

\section{Взаимодействие кислорода и монооксида углерода с микропористыми пленками Со(II) порфирина с объемными mpem-бутильными заместителями при низких температурах}

\author{
Т. С. Куртикян, ${ }^{a}$ А. А. Ховханнисян, ${ }^{a}$ А. В. Аюбимцев, ${ }^{\text {b }}$ Т. А. Агеева, ${ }^{\mathrm{b}}$ \\ В. С. Угаров, ${ }^{\text {' }}$ О. И. Койфман ${ }^{\text {' }}$
}

ацентр исследования строения молекул Научно-технологического центтра органической и фармацевтической химии, 0014 Ереван, Армения

${ }^{\mathrm{b}}$ НИИ химии макрогетероциклических соединений, Ивановский государственный химико-технологический университет, 153000 Иваново, Россия

${ }^{\circledR}$ E-mail: kurto@netsys.am 
Методами Фурье-ИК и электронной абсорбционной спектроскопии исследовано низкотемпературное взаимодействие двухатомных молекул (O, СО) и их смесей с пленками 5,10,15,20-тетракис(3',5'-дитретбутилфенил)порфирината кобальта(II) (I) и 5-(пиридин-4'-ил)-10,15,20-трис(3',5'-ди-третбутилфенил) порфирината кобальта(II) (II), полученными сублимацией металлокомплексов в высоком вакууме. В отличие от слоев мезо-тетрафенилпорфирината кобальта(II) (СоТФП), быстро теряющих свою микропористость при хранении в вакууме при комнатных температурах, слои I сохраняют свою микропористость в течение продожительного времени. Наличие объемных трет-бутильных заместителей в значительной степени замедляет процесс уплотнения пленок и при исследовании обратимых сорбционных процессов одна и та же пленка может быть использована многократно. Показано, что слои II состоят из координационных олигомеров, в которых пиридильная группа одной молекуль координируется с ионом Со соседней молекуль в слое. Степень олигомеризации зависит от условий получения и заметно выше в пленках, полученных сублимаџией на подложку, поддерживаемую при повышенных температурах, по сравнению со слоями, осажденными на низкотемпературную поверхность. Сравнением полученных данных с теми же для пленок $\boldsymbol{I}$ вылвлено, что в пленках II кислород образует два типа комплексов - 5-координационных в конце олигомерной цеепи и 6-координационных в остальныл звеньях. В последних в качестве шестого лиганда выступает координированная пиридильная группа соседней молекуль в пленке. Моноксид же углерода координируется исключительно в коние олигомера, оставляя шестое координационное положение в олигомерах свободным. При подаче в криостат с пленкой II смеси СО/O, эти положения селективно связывают $\mathrm{O}_{2}$. Это дает возможность удалить кислород из газовых смесей СО/O 2 с малым его содержанием и, тем самым, очистить СО от следовых количеств кислорода.

Ключевые слова: Микропористые пленки, координационные олигомеры, порфиринаты кобальта(II), объемные периферийные заместители, Фурье-ИК, электронная абсорбционная спектроскопия, координация О, и СО, низкие температуры.

\section{Introduction}

The construction of microporous materials containing metal ions in their network is an attractive tool for tailoring materials with useful chemoresponsive properties. ${ }^{[1-3]}$ Metalloporphyrins are exclusively convenient molecules for acting as a building blocks for the construction of different microporous solids, since countless derivatives can be obtained by variation of the nature of the central metal ion and by inclusion of the various substituents in the periphery of the molecule. ${ }^{[4-6]}$

Thin films of porphyrin-like compounds have gained much interest as field and chemo-responsive materials because of their potential application in gas-sensing devices, selective adsorbents, heterogeneous catalytic systems, etc. ${ }^{[7-10]}$ Some metalloporphyrins, including Co-derivatives, are also efficient oxygen carriers and have been studied for potential application as oxygen adsorbents, artifitial hemoglobin and oxygenpermoselective membrans. ${ }^{[11-13]}$ In order to generate the films with useful properties, it is desirable to create porous systems in which not only surface molecules but also those in the bulk of layer would be active. It has previously been shown that the layers of meso-tetraphenylporphyrinatocobalt (CoTPP), obtained by sublimation on the low-temperature substrate are microporous and reversibly bind dioxygen. ${ }^{[14]}$ However, upon storing at ambient conditions they lose this ability due to close packing of the molecules in the layer thereby inhibiting the diffusion of gaseous molecules in the bulk of layer.

We proposed that the presence of bulky tert-butyl groups in the periphery of molecules will prevent close packing of the molecules in the films or at least will slow down the rate of this process, so the same film would conserve its porosity longer and could be used repeatedly. In this paper we describe the studies of $\mathrm{O}_{2}$ and $\mathrm{CO}$ interaction with sublimed films of I and II, in which we found that the films of II reveal some specificity in binding of these ligands and can be used for purification of $\mathrm{CO} / \mathrm{O}_{2}$ mixtures of trace amounts of $\mathrm{O}_{2}$.

\section{Experimental}

Metal free 5-(4-pyridin-4-yl)-10,15,20-tris(3,5-di-tertbutylphenyl)porphyrin was synthesized by the condensation of 4-pyridinecarboxaldehyde (1 eq.), 3,5-di-tert-butylbenzaldehyde (3 eq.) and pyrrole (4 eq.) in propionic acid according to the documented procedure. ${ }^{[15]}$ Symmetrical metal free 5,10,15,20-tetrakis(3,5-ditert-butylphenyl)porphyrin was obtained as co-product. Co(II) complexes I and II were prepared from free ligands by reflux with cobalt acetate in DMF. Porphyrins I and II were purified through a column of $\mathrm{Al}_{2} \mathrm{O}_{3}$ and eluted with $\mathrm{CHCl}_{3}-\mathrm{MeOH}(100: 0.5)$ mixture.

The Co-porphyrins I and II were placed in the Knudsen cell and heated up to $\sim 450 \mathrm{~K}$ under high vacuum for the removal of the solvated molecules. Then the cryostat was filled with liquid nitrogen and the temperature of the Knudsen cell was raised up to $\sim 500 \mathrm{~K}$ and $550 \mathrm{~K}$ for I and II correspondingly, where these metal complexes were sublimed onto a $\mathrm{KBr}$ (for FTIR measurements) or $\mathrm{CaF}_{2}$ (for UV-visible measurements) substrates. The films of II were obtained also by sublimation onto substrates, maintained at room temperature or heated to $323 \mathrm{~K}$. In order to obtain layers with thicknesses suitable for infrared and UV-visible measurements, the deposition was performed for 1.5-2 and 0.5 hours respectively. Molecular oxygen was stored in cylinders with $\mathrm{P}_{2} \mathrm{O}_{5}$ for the removal of the trace amounts of moisture. ${ }^{18} \mathrm{O}_{2}$ gas was with $95 \%$ enrichment was acquired from the Cambridge isotopic laboratories, $\mathrm{C}^{18} \mathrm{O}$ with $81.4 \%$ enrichment from the Institute of isotopes, Republic of Georgia.

The layers of II obtained via sublimation onto a low temperature substrate were heated up to room temperature and kept in vacuum overnight. Different quantities of $\mathrm{O}_{2}, \mathrm{CO}$ or their mixtures controlled by mercury monometer or by thermocouple gauge were then introduced into the cryostat at $\mathrm{LN}_{2}$ and annealed 
to assist the formation of complexes. The layer was then slowly warmed to room temperature and the FTIR or UV-visible spectra were obtained at various controlled temperatures measured by a thermocouple. The UV-visible spectra were taken after the FTIR measurements of the same samples confirmed the identity of each species. The FTIR and UV-visible spectra were acquired on a Nexus (Thermo Nicolet Corporation) in the spectral range 400-4000 $\mathrm{cm}^{-1}$ with a resolution $2 \mathrm{~cm}^{-1}$ and Specord M-40 (Carl Zeiss, Jena) or Helios $\gamma$ (Thermo Nicolet Corporation) spectrometers in the range of 350-900 nm, respectively.

\section{Results and Discussion}

\section{The Interaction of $\mathrm{O}_{2}$ and $\mathrm{CO}$ with Films of $\boldsymbol{I}$}

It was previously shown that similar to the matrixisolated molecules of $\mathrm{Co}(\mathrm{TPP}),{ }^{[16]}$ its layers, obtained by sublimation onto the low-temperature substrate, are also able to bind dioxygen $\mathrm{O}_{2}$ and carbon monoxide CO. ${ }^{[14,17]}$ However, during storage at ambient conditions overnight they lose this ability due to close packing of the molecules in the layer and dramatically decreased cross section of the pores that prevents the diffusion of potential ligands in to the bulk of layer.

Similarly to Co(TPP), sublimed layers of I (Scheme 1) also form dioxygen adduct upon low-temperature reaction with $\mathrm{O}_{2}$ gas as is demonstrated by the FTIR spectral changes represented in Figure 1. New band in the vicinity of $1250 \mathrm{~cm}^{-1}$ appears in the spectrum that overlaps the band of porphyrin itself drastically enhancing its intensity. When ${ }^{18} \mathrm{O}_{2}$ is used in the experiment this band is shifted to $1180 \mathrm{~cm}^{-1}$. From the value of this isotopic shift, and by analogy with previous work, ${ }^{[18]}$ these bands can be readily assigned to coordinated dioxygen in the adducts $(\mathrm{I})\left({ }^{16} \mathrm{O}_{2}\right)$ and $(\mathrm{I})\left({ }^{18} \mathrm{O}_{2}\right)$.

Low-temperature interaction of $\mathrm{CO}$ with the film of I leads to the appearance of two bands in the range of $\mathrm{CO}$ stretching frequency at 2131 and $2058 \mathrm{~cm}^{-1}$, which shift to 2080 and $2011 \mathrm{~cm}^{-1}$ when isotopic $\mathrm{C}^{18} \mathrm{O}$ is used in the experiments (see Figure 5). The band at 2058 (2011 for $\mathrm{C}^{18} \mathrm{O}$ ) $\mathrm{cm}^{-1}$ by analogy with the matrix-isolation study of Kozuka and Nakamoto ${ }^{[16]}$ and our work with sublimed layers of Co(TPP) ${ }^{[17]}$ should be assigned to the adducts $(\mathrm{I})(\mathrm{CO})$ and $(\mathrm{I})\left(\mathrm{C}^{18} \mathrm{O}\right)$.

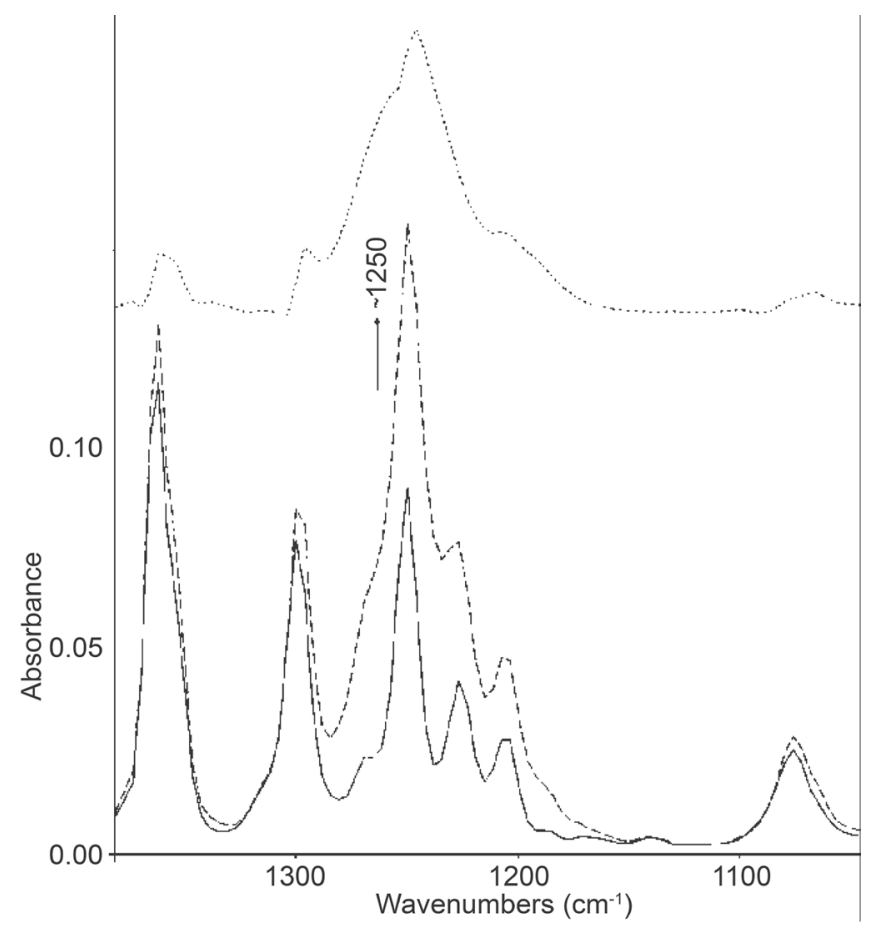

Figure 1. FTIR spectra of the film of I at $80 \mathrm{~K}$ (solid line) after exposure to 60 Torr $\mathrm{O}_{2}$ and annealing in the cycle $80 \mathrm{~K} \rightarrow 120 \mathrm{~K}$ $\rightarrow 80 \mathrm{~K}$ (dashed line) and difference spectrum (dotted line).

The high frequency band at 2031 (2080), previously observed upon $\mathrm{CO}$ interaction with the low-temperature microporous layers of Co(TPP) and assigned to the physically adsorbed $\mathrm{CO},{ }^{[17]}$ must be of the same nature. Except for minor changes in the frequencies of absorption bands of coordinated ligands there are no principal differences regarding to interaction of these diatomics with the films of Co(TPP) and $\mathbf{I}$, what is to be expected. Another thing is important. In contrast to the layers of $\mathrm{Co}$ (TPP), that lose their reversible ligand-binding ability already during storage overnight, the films of I remain active for a long time. The films, stored within two weeks at a room temperature showed decrease in the amount of coordinated oxygen only $\sim 20 \%$. Thus, the process of close packing in the films is substantially slowed down due to the presence in their structure of tert-butyl bulky substituents.

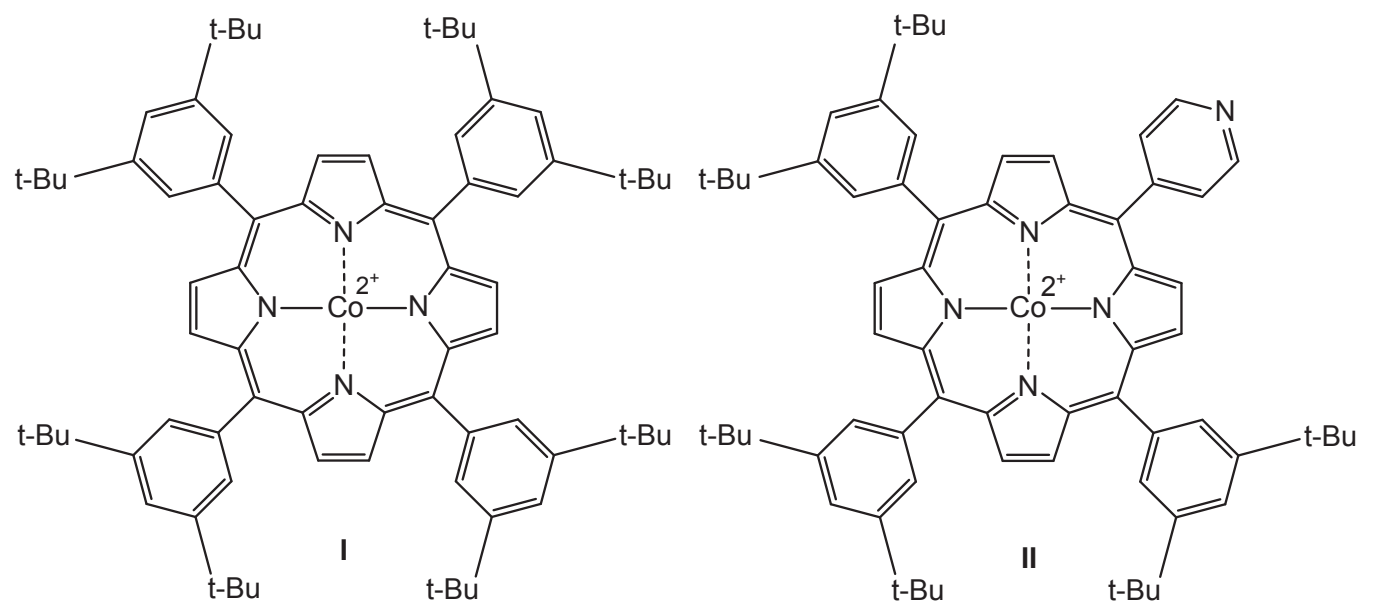

Scheme 1. 
Thereby, in the studies of reversible processes the same film can be used multiple times that created a lot of flexibility and resulted in a saving of expensive material.

\section{The Interaction of $\mathrm{O}_{2}$ and $\mathrm{CO}$ with Films of $\mathbf{I I}$}

Admission of $\mathrm{O}_{2}$ gas into cryostat containing sublimed film of II leads to the FTIR spectrum represented in Figure 2. It reveals two new bands, one in the vicinity of 1250 $\mathrm{cm}^{-1}$ analogous to that appeared for the film of I (see Figure 1) and assigned to the complex $(\mathbf{I})\left(\mathrm{O}_{2}\right)$ and another one at $1168 \mathrm{~cm}^{-1}$. The same procedure with isotopically enriched ${ }^{18} \mathrm{O}_{2}$ shifts these bands to $\sim 1180$ and $1108 \mathrm{~cm}{ }^{1}$ (Figure 2) correspondingly. This isotopic dependence confirms its assignment as a dioxygen stretching mode, and indicates the formation of another type of complex. After the support is heated to room temperature, both bands disappear and the initial spectrum is restored. On admission of new portions of $\mathrm{O}_{2}$, these bands appear again, but the intensity of the low-frequency band increases at the expense of the highfrequency band.

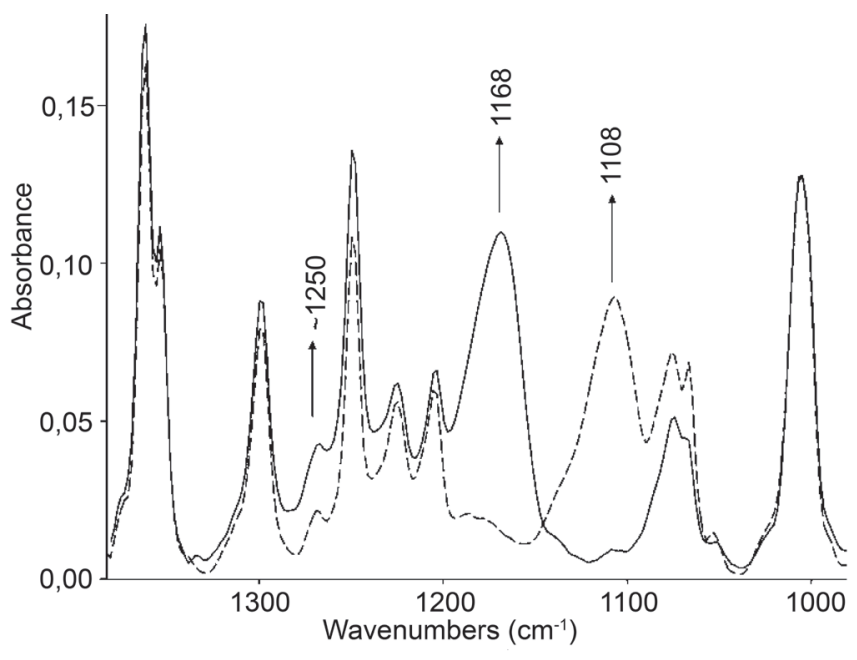

Figure 2. FTIR spectra of the film of II after exposure to 60 Torr $\mathrm{O}_{2}$ and annealing in the cycle $80 \mathrm{~K} \rightarrow 120 \mathrm{~K} \rightarrow 80 \mathrm{~K}$ (solid line); the same in the presence of 6 Torr ${ }^{18} \mathrm{O}_{2}$ (dashed line).

The ratio of intensities of the low- and high-frequency bands depends on the conditions of film preparation. Upon storage of the films, the concentration of six-coordinate complexes increases at the expense of the five-coordinate species. It is also higher when during sublimation the substrate was maintained at higher temperatures (Figure 3).

The results obtained are very close to those observed for the films of Co(II) complex of 5-(pyridin-4-yl)-10,15,20triphenylporphyrin (Co(M4PyTPP) $)^{[18,19]}$ and explained in terms of formation of coordinatively linked oligomers and formation of a six-coordinate dioxygen adduct with the pyridyl base in the trans axial position. The same pattern was observed upon interaction of $\mathrm{O}_{2}$ with sublimed layers of Fe(M4PyTPP).[20] Hence despite the presence of bulky tert-butyl groups the same type of oligomers (Scheme 2) is formed in the films of II too. The six-coordinate dioxygen complexes formed by oligomeric units are thermally much

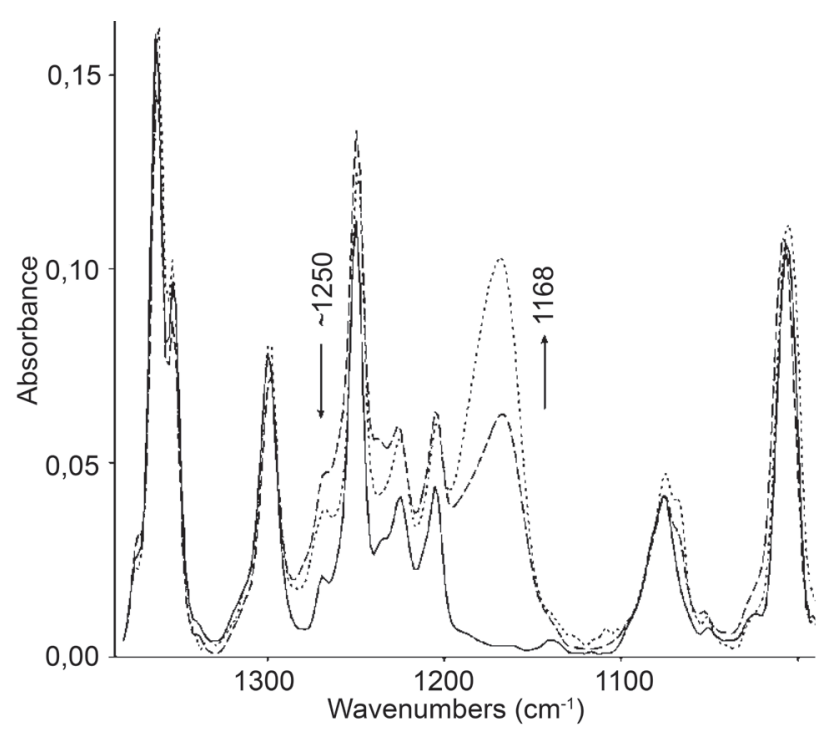

Figure 3. FTIR spectra of the film of II at $80 \mathrm{~K}$ in the range of $\mathrm{O}_{2}$ stretching mode: initial spectrum (solid line) after admission of $\mathrm{O}_{2}$ gas on the film obtained by sublimation onto the low-temperature $(80 \mathrm{~K})$ substrate (dashed line), after admission of $\mathrm{O}_{2}$ gas on the film obtained by sublimation on the substrate, maintained at $323 \mathrm{~K}$ (dotted line).

more stable than five-coordinate dioxygen complexes that terminate the oligomers.

The electronic absorption spectrum of II also undergoes noticeable changes in the course of interaction with $\mathrm{O}_{2}$. As seen in the Figure 4 the band of II in the visible range at $532 \mathrm{~nm}$ shifts to $534 \mathrm{~nm}$ and displays a shoulder at $588 \mathrm{~nm}$ upon formation of dioxygen complexes.

Thus the interaction of $\mathrm{O}_{2}$ gas with the films of $\mathbf{I}$ and II is significantly different. At the same time the interaction of $\mathrm{CO}$ with these films leads to almost identical results with two bands in the range of $\mathrm{CO}$ stretching vibration. The highfrequency bands are close in frequency to the $v(\mathrm{CO})$ of gas phase $\left(v=2141 \mathrm{~cm}^{-1}\right)$ and matrix-isolated $\left(v=2137 \mathrm{~cm}^{-1}\right)$ $\mathrm{CO}$ and should be assigned to the $v(\mathrm{CO})$ of $\mathrm{CO}$ molecules adsorbed in films. ${ }^{[16]}$ Upon films warming these bands

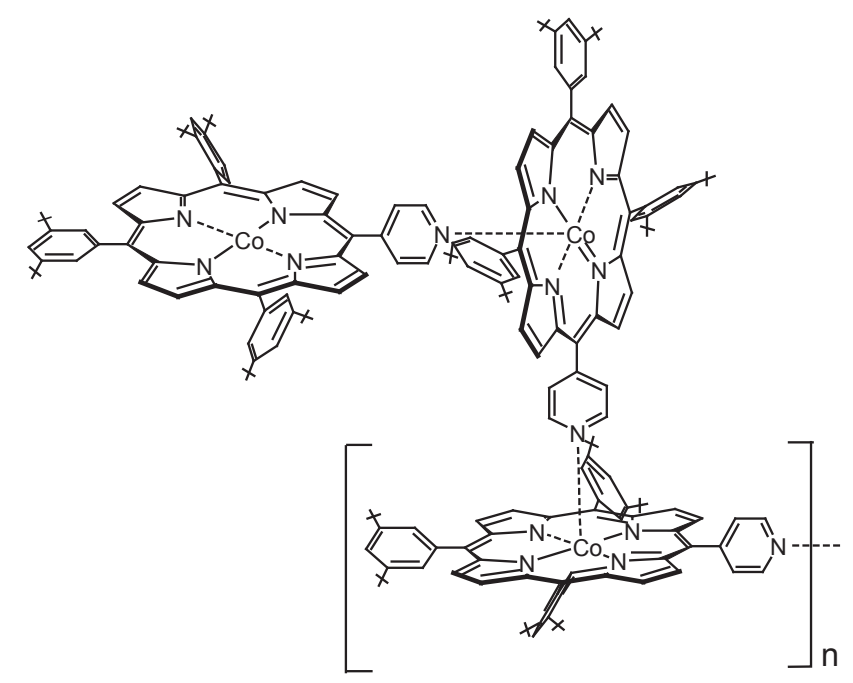

Scheme 2. 


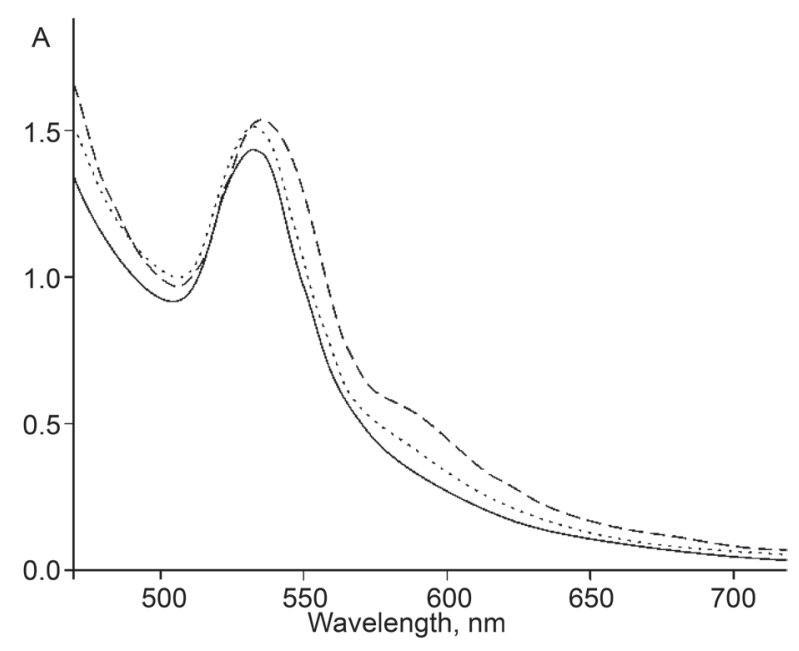

Figure 4. UV-visible spectra of II (solid line) after lowtemperature interaction with $\mathrm{O}_{2}$ (dashed line) and $\mathrm{CO}$ (dotted line). The spectra were taken after FTIR measurements of the same samples confirming the identity of each species.

disappear first, indicating the low energy of $\mathrm{CO}$ binding. The low-frequency bands are close in frequency to each other and to the value of the $v(\mathrm{CO})$ in monocarbonyl complex $\operatorname{Co}(\mathrm{TPP})(\mathrm{CO})\left(\mathrm{v}=2066 \mathrm{~cm}^{-1}\right)^{[16,17]}$ and can be also assigned to monocarbonyl complexes. There is no any spectral feature indicating formation of the six-coordinate carbonyl complex with the trans-pyridyl group of neighboring molecule in the film.

It must not be ruled out, that coordination of $\mathrm{CO}$ could lead to the disruption of the bond between Co-ion and pyridyl group of an adjacent molecule, leading actually to the destruction of oligomeric structure in a film. In this case only formation of the 5-coordinate monocarbonyl complexes (II)(CO) should be expected. The closely related pattern took place in the course of interaction of the other diatomic molecule, NO, with the heme of the soluble guanylyl-cyclase, leading to disruption of the Fe-histidine bond, followed by enzyme conformation changes and its more than 200-fold activation. ${ }^{[21]}$ Following experimental observation, however, excludes such possibility.

The equal quantities of $\mathrm{CO}$ were admitted into the cryostat with films of I and II. Using the intensities of the $v(\mathrm{CO})$ band the relative amounts of $\mathrm{CO}$ coordinated by these films were estimated. The intensity of band at about $1000 \mathrm{~cm}^{-1}$ was chosen as a reference. This band is present in all meso-tetraaryl substituted porphyrins and their metal complexes and corresponds to the mixed $\delta_{\text {sym }}(\mathrm{C}-\mathrm{C}-\mathrm{C})+v($ Pyr. Breathing $)$ $+v_{\text {asym }}$ (Pyr. Half-ring) mode. ${ }^{\text {sym }}$ Assuming in rough approximation that in the films of I and II these bands are approximately equal intensity, it can be concluded from the spectra of Figure 5 that the amount of coordinated $\mathrm{CO}$ in the films of II about three times less than in the film of I. Here we assume that substitution of one 3',5'-di-tert-butylphenyl ring by pyridyl ring should not significantly change the extinction coefficient of the coordinated CO moiety. It means in turn that only one third of molecules in the film of II coordinates $\mathrm{CO}$ molecules. This observation is in contrast with the assumption that $\mathrm{CO}$ coordination results in disruption of the

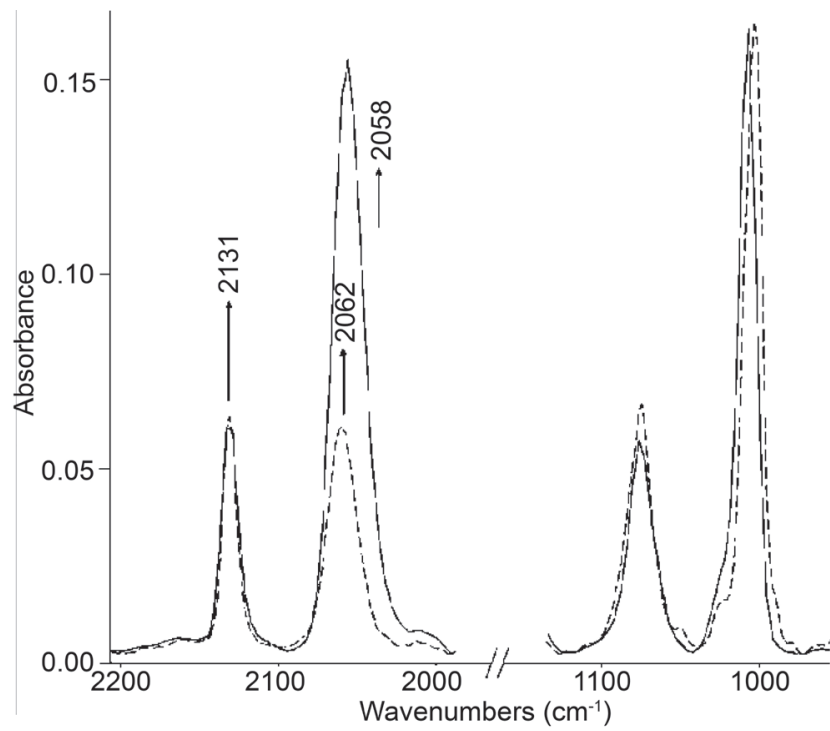

Figure 5. FTIR spectra of the films of I (solid line) and II (dashed line ) after exposure to 40 Torr $\mathrm{CO}$ and annealing in the cycle $80 \mathrm{~K} \rightarrow 120 \mathrm{~K} \rightarrow 80 \mathrm{~K}$ (solid line). Gas phase $\mathrm{CO}$ was pumped out at $80 \mathrm{~K}$.

Co-pyridyl bond. From these data the circumstantial information about the degree of oligomerization can be obtained, which is equal to three in average.

Only minor changes are observed in the electronic absorption spectrum of the film of II after interaction with $\mathrm{CO}$ (Figure 4, dotted line). It is easy to understand since only small part of II is engaged in coordination with $\mathrm{CO}$.

The absence of the 6-coordinated carbon monoxide complex with trans pyridyl ligand is not surprising. Hoffman and Petering did not find any evidence of such a complex formation upon interaction of one atmosphere $\mathrm{CO}$ with deoxy-coboglobin. ${ }^{[22]}$ In this protein the proximal ligand was histidine. Moreover, studies on the model $\mathrm{Co}(\mathrm{P})$-dimethyl ester (P-protoporphyrin-IX) in organic solvents containing nitrogen bases also fail to detect coordinated $\mathrm{CO}$, as was demonstrated by ESR and optical absorption methods. ${ }^{[23]}$

As it was mentioned above the storage of the films of II leads to the increase of degree of oligomerization. It will affect the relative amounts of coordinated dioxygen and carbon monoxide. As seen in Figure 6, upon storage of the film of II under vapor of $\mathrm{CO} / \mathrm{O}_{2}$ mixture the amount of the 6-coordinate dioxygen adduct (band at $1168 \mathrm{~cm}^{-1}$ ) increase at the expense of the coordinated carbon monoxide (band at $2064 \mathrm{~cm}^{-1}$ ). This observation also indicates that $\mathrm{CO}$ is coordinated exclusively with the end group of oligomers (Scheme 3).

As it was noted above in the presence of $\mathrm{CO}$ the sixth coordination site of oligomers in the films of II remains free. Therefore upon supplying of a $\mathrm{CO} / \mathrm{O}_{2}$ mixture into cryostat these ligands do not compete for binding with those metal centers that included in oligomers. By this reason even very low quantities of $\mathrm{O}_{2}$ in the mixture can be captured by the films of II. The Figure 7a represents the FTIR spectral changes accompanying the interaction of $\mathrm{CO} / \mathrm{O}_{2}$ mixture containing 10 Torr $\mathrm{CO}$ and 0.01 Torr $\mathrm{O}_{2}$ with the film of II. The band $v\left(\mathrm{O}_{2}\right)$ of the 6-coordinated dioxygen even at such low pressure is seen 


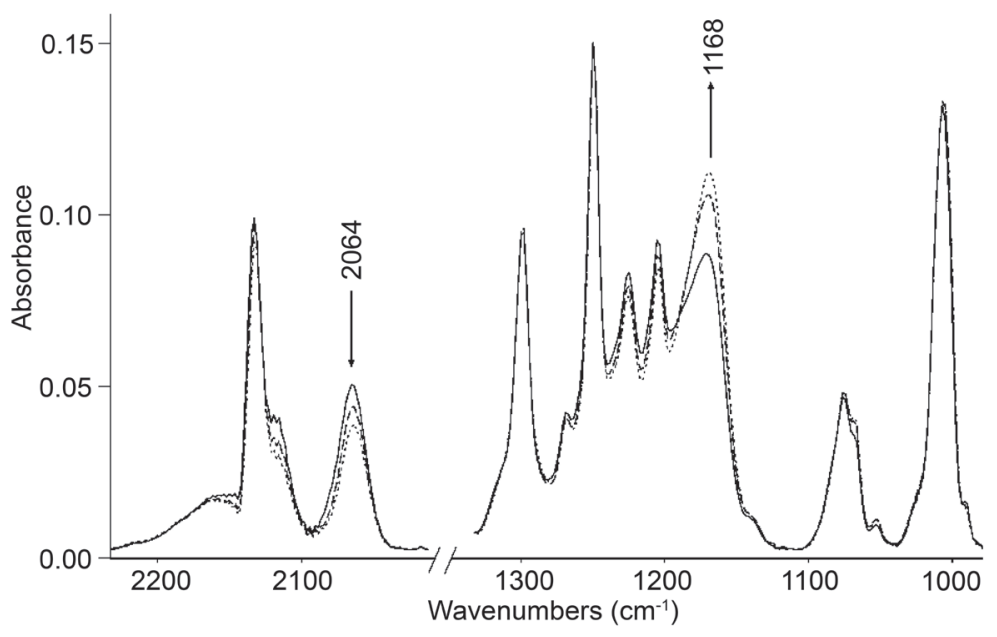

Figure 6. FTIR spectra of the film of II exposed to 15 Torr of $\mathrm{O}_{2} / \mathrm{CO}(1: 1)$ mixture and annealed in the cycle $80 \mathrm{~K} \rightarrow 120 \mathrm{~K} \rightarrow 80 \mathrm{~K}$ (solid line) after warming to $300 \mathrm{~K}$ and recooling to $80 \mathrm{~K}$ (dashed line) and after storage under $\mathrm{O}_{2} / \mathrm{CO}$ atmosphere overnight (dotted line).

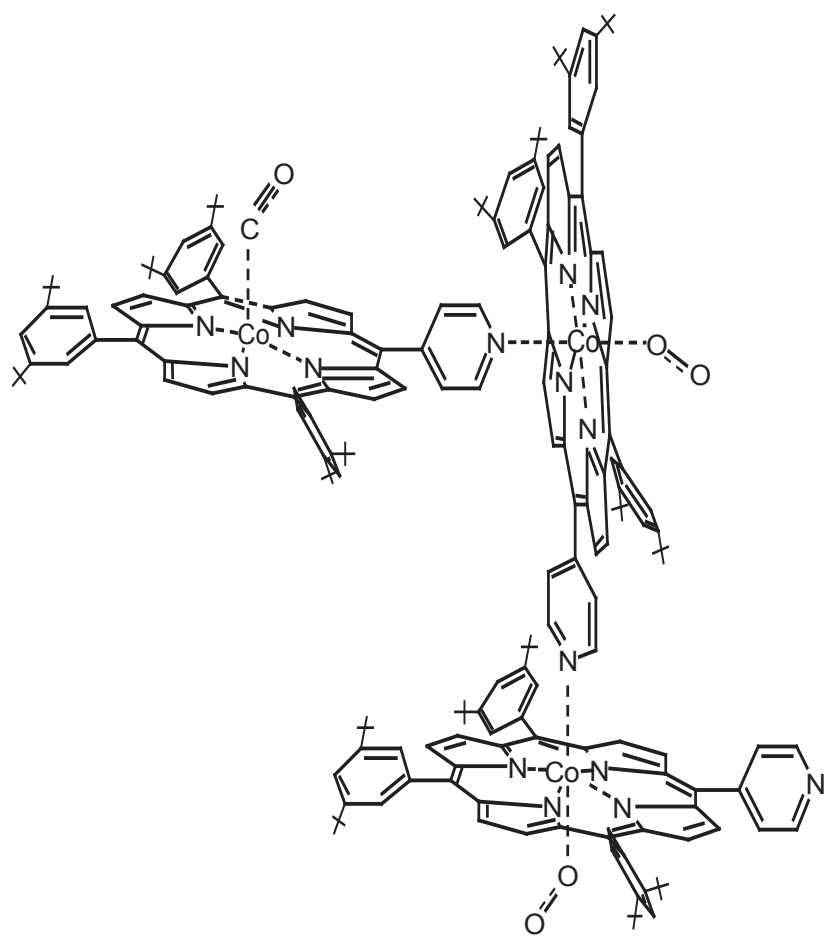

Scheme 3.

quite clearly, despite of the presence of large $\mathrm{CO}$ excess. At the same time interaction of $\mathrm{CO} / \mathrm{O}_{2}$ mixture with films of $\mathbf{I}$ even at higher pressure of $\mathrm{O}_{2}$ and smaller ratio of $\mathrm{CO} /{ }^{18} \mathrm{O}_{2}$ does not reveal detectable quantities of coordinated ${ }^{18} \mathrm{O}_{2}$ (Figure 7b). In this experiment the isotopic ${ }^{18} \mathrm{O}_{2}$ was used because the weak band of coordinated $\mathrm{O}_{2}$ disposed in the vicinity of $1250 \mathrm{~cm}^{-1}$ could not be clearly seen due to the presence of the intense porphyrin bands in this spectral range. The $v\left({ }^{18} \mathrm{O}_{2}\right)$ of coordinated ${ }^{18} \mathrm{O}_{2}$ is disposed in the $1180 \mathrm{~cm}^{-1}$ range free of the bands of porphyrin itself and should be clearly seen if such adduct is formed during reaction of $\mathrm{CO} /{ }^{18} \mathrm{O}$, with $\mathbf{I}$. Obviously upon reaction with films of $\mathbf{I}$ the competition between $\mathrm{CO}$ and $\mathrm{O}_{2}$ ligands for the binding with vacant metal sites in conditions when $\mathrm{CO}>>{ }^{18} \mathrm{O}_{2}$ would lead to the negligibly small quantities of coordinated $\mathrm{O}_{2}$ that could not be detected spectrally. The data obtained clearly show that the films of II preferentially bind dioxygen from the $\mathrm{CO} / \mathrm{O}_{2}$ mixture and can be used for their purification from trace amounts of $\mathrm{O}_{2}$.

\section{Conclusions}

Sublimed layers of Co(II) complex of 5,10,15,20-tetrakis(3',5'-di-tert-butylphenyl)porphyrin (I), in contrast to the layers of $[5,10,15,20$-tetraphenylporphyrinato $]$ cobalt(II) Co(TPP) that lose their porosity and ligand-binding ability upon standing at ambient conditions, conserve these properties for a long time. Obviously, the bulky tert-butyl groups of I slow down the close packing of molecules in the films making metal ions accessible to different ligands for a long period. As a result these films can be repeatedly used for various applications. The self-assembly of $\mathrm{Co}$ (II) complex of 5-(pyridin-4'-yl)-10,15,20-tris(3',5'-di-tert-butylphenyl) porphyrin (II) in sublimed layers leads to the formation of one-dimensional coordination oligomers, in which the pyridyl group of one molecule is coordinated with the metal ion of an adjacent molecule in the layer. The low temperature interaction of $\mathrm{O}_{2}\left({ }^{18} \mathrm{O}_{2}\right)$, $\mathrm{CO}\left(\mathrm{C}^{18} \mathrm{O}\right)$ and their mixtures with the films of I and II studied by FTIR and UV-vis spectroscopy shows that films of II reveal different binding properties in relation to these ligands. Both the 5- and 6-coordinate complexes are formed with $\mathrm{O}_{2}$-ligand, the former at the end of oligomers and the latter with one coordination site occupied by the pyridyl group of an adjacent molecule, while only the end group of oligomers binds $\mathrm{CO}$, forming exclusively 5-coordinate species. As a consequence the films of II, revealing different binding abilities in relation to $\mathrm{O}_{2}$ and $\mathrm{CO}$, can be used for practical purposes, particularly, for purification of $\mathrm{CO} / \mathrm{O}_{2}$ mixture from trace amounts of $\mathrm{O}_{2}$.

Acknowledgement. This work was supported by the State Committee of Science RA (Grant№ 15RF-055) and the Russian Foundation for Basic Research (Project № 15-53-05072 Arm_a). 


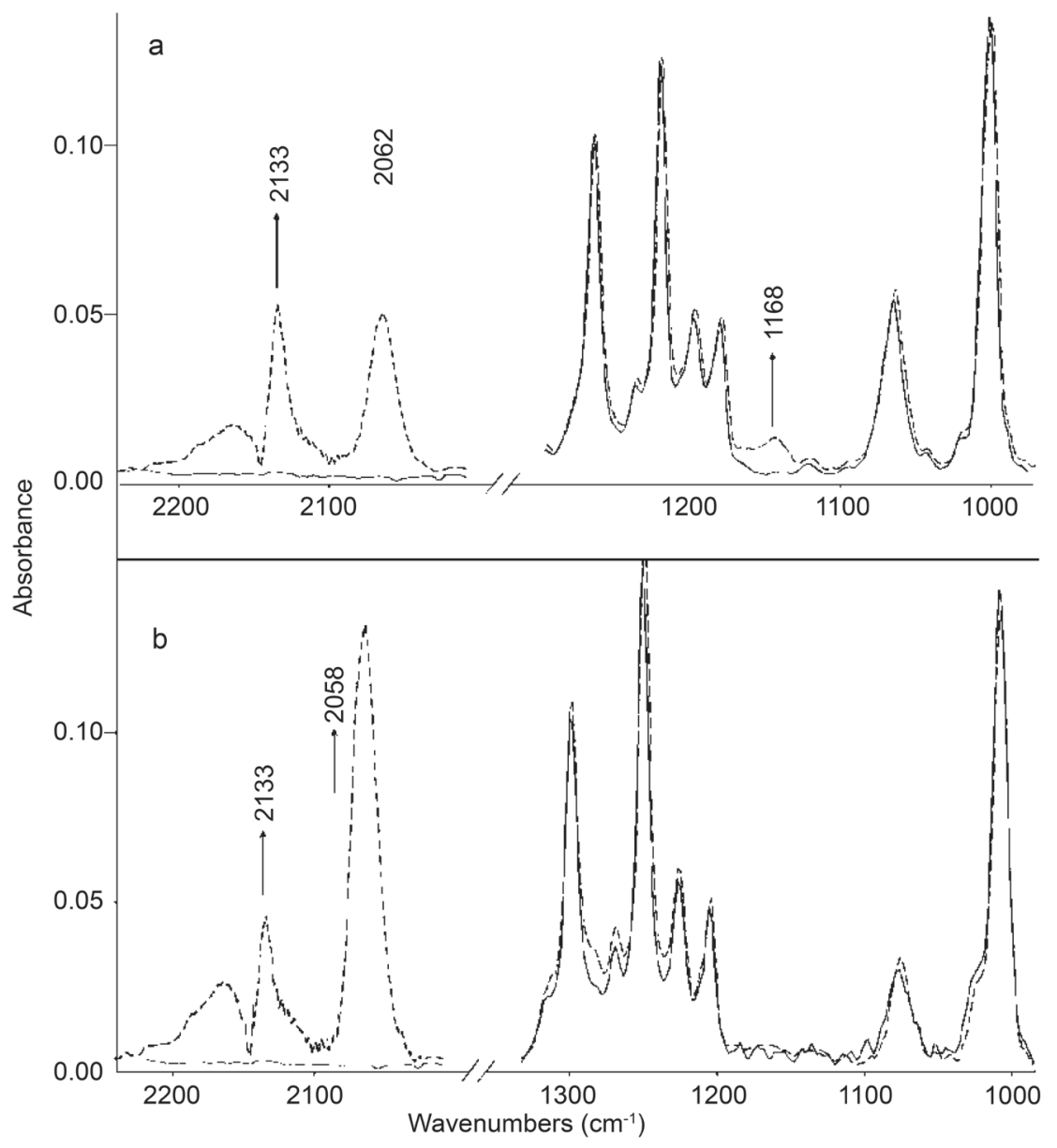

Figure 7. (a) FTIR spectra of the film II (solid line) after interaction with the gaseous mixture containing 10 Torr $\mathrm{CO}$ and 0.01 Torr of $\mathrm{O}_{2}$ (dashed line); (b) FTIR spectra of the film I (solid line) after interaction with the gaseous mixture containing 15 Torr CO and 0.15 Torr of ${ }^{18} \mathrm{O}_{2}$ (dashed line). The mixtures was admitted into the cryostat at room temperature and cooled to $80 \mathrm{~K}$. The broad band in the $2100-$ $2200 \mathrm{~cm}^{-1}$ range is of the gas phase $\mathrm{CO}$.

\section{References}

1. Tranchemontagne D.J., Mendoza-Cortes J.L., O'Keefe M., Yaghi O.M. Chem. Soc. Rev. 2009, 38, 1257-1283.

2. Wang Z., Yuan S., Mason A., Reprogle B., Liu D.-J., Yu L. Macromolecules 2012, 45, 7413-7419.

3. Kaushik A., Kumar R., Arya S.K., Nair M., Malhotra B.D., Bhansali S. Chem. Rev. 2015, 115, 4571-4606.

4. Synthesis and Modification of Porphyrinoids (Paolesse R., Ed.), Springer-Verlag Berlin Heidelberg, 2014. 300 p.

5. Suslick K.S., Bhyrappa P., Chou J.-H., Kosal M.E., Nakagaki S., Smitherny D., Wilson S.R. Acc. Chem. Res. 2005, 38, 283-291.

6. Park J.H., Ko J.H., Hong S., Shin Y.J., Park N., Kang S., Lee S.M., Kim H.J., Son S.U. Chem. Mater. 2015, 27, 5845-5848.

7. Tonezzer M., Maggioni G., Dalcanale E. J. Mater. Chem. 2012, 22, 5647-5655.

8. Martirosyan G.G., Kurtikyan T.S. J. Appl. Chem. 1998, 71, 1595-1600.

9. So M.C., Jin S., Son H.-J., Wiederrecht G.P., Farha O.K., Hupp J.T. J. Am. Chem. Soc. 2013, 135, 15698-15701.

10. Makiura R., Motoyama S., Umemura Y., Yamanaka H., Sakata O., Kitagawa H. Nature Mater. 2010, 9, 565-571.

11. Nishide H., Chen X.-S., Tsuchida E. In: Functional Monomers and Polymers, $2^{\text {nd }}$ ed. (Takemoto K., Kamachi M., Ottenbright
R.M., Eds.), Marcel Deccer Inc.: New York, 1997. p. 173.

12. Artificial Red Cells: Materials, Performances and Clinical Study As Blood Substitutes (Tsuchida E., Ed.), John Wiley @, Sons Inc.: New York, 1995.

13. Nishide H., Tsukahara Y., Tsuchida E. J. Phys. Chem. B 1998, 102, 8766-8770.

14. Kurtikyan T.S., Gasparyan A.V., Martirosyan G.G., Zhamkochyan G.H. Zh. Prikl. Spektrosk. 1995, 62, 62-66 (in Russ.).

15. Kurotobi K., Osuka A. Org. Lett. 2005, 7, 1055-1058.

16. Kozuka M., Nakamoto K. J. Am. Chem. Soc. 1981, 103, $2162-2168$.

17. Kurtikyan T.S., Martirosyan G.G., Akopyan M.E. Kinet. Catal. 2001, 42, 281-288.

18. Kurtikyan T.S., Martirosyan G.G., Kazaryan R.K., Madakyan V.N. Russ. Chem. Bull. 2001, 50, 638-640.

19. Kurtikyan T.S., Ogden J.S., Kazaryan R.K., Madakyan V.N. Eur. J. Inorg. Chem. 2003, 1861-1865.

20. Kurtikyan T.S., Ogden J.S., Kazaryan R.K., Madakyan V.N. J. Porphyrins Phthalocyanines 2003, 7, 623-629.

21. Stone J.R., Marletta M.A. Biochemistry 1994, 33, 5636-5640.

22. Paulat F., Praneeth V.K.K., Näther C., Lehnert N. Inorg. Chem. 2006, 45, 2835-2856.

23. Hoffman B.B., Petering D.H. Proc. Natl. Acad. Sci. 1970, 67 , 637-643. 